\title{
Concentrations and dynamics of free mono- and oligosaccharides in a shallow eutrophic lake measured by thermospray mass spectrometry
}

\author{
Benedikt Meon*, Friedrich Jüttner \\ Institute of Plant Biology/Limnology, University of Zürich, Limnological Station, Seestr. 187, \\ CH-8802 Kilchberg, Switzerland
}

\begin{abstract}
Short-term, diel and annual variations in sugar concentrations (hexoses and oligosaccharides) were determined in a shallow eutrophic lake (Lake Au. Switzerland) by high performance liquid chromatography-thermospray mass spectrometry (HPLC-TSMS), a technique previously not used for the quantitative determination of mono- and oligosaccharides in aquatic environments. Concentrations of total hexoses and total disaccharides were extremely low in comparison to previous studies and showed little variations on an annual time scale with values $<1$ to $48 \mathrm{nM}$ (mean: $13 \mathrm{nM}$ ) and $<1$ to $77 \mathrm{nM}$ (mean: $9 \mathrm{nM}$ ), respectively. The low values can be attributed to the reliability of the mass spectrometric method that used labelled internal standards, which were added immediately after sampling, and the use of hollow-fibre filtration to remove delicate organisms without damage from the soluble fraction. The low concentrations also indicate the existence of high affinity sugar uptake systems in aquatic microbial communities. Trisaccharide and tetrasaccharide concentrations were below the detection limit of $2 \mathrm{nM}$ on most sampling dates. The total carbon content of the mono- and oligosaccharides represented 0.003 to $0.3 \%$ of the dissolved organic carbon (DOC). We observed neither a trend in sugar concentration over the year, nor a dependence on phytoplankton density, but transient pulses of sugar concentrations occurred on an hourly time scale, suggesting a tight coupling between release and uptake of sugars. Average decrease rates of oligosaccharides (maltose, maltotriose, maltotetraose) that were added as substrates to in situ exposed $5 \mathrm{l}$ microcosms ranged between 27 and $50 \mathrm{nmol} \mathrm{l}^{-1} \mathrm{~h}^{-1}$. Both the high decrease rates and the absence of cleavage products in the course of the incubations support the assumption that uptake of intact oligosaccharides by microheterotrophs was responsible for the decrease in concentrations. Furthermore, the immediate decrease of the added maltooligosaccharides demonstrate that these sugars are frequently used substrates in lakewater. This could not be confirmed for 3-O- $\beta$-galactopyranosyl-D-arabinose, for which a decrease in concentration was only observed after $29 \mathrm{~h}$. These experiments indicate that the sugar composition of oligosaccharides and their type of linkage are important features influencing their bioavailability to microheterotrophs.
\end{abstract}

KEY WORDS: Thermospray mass spectrometry - Dissolved free carbohydrates $\cdot$ DOC Oligosaccharides - Sugar dynamics - Lakewater

\section{INTRODUCTION}

Dissolved carbohydrates (DCHO) are important carbon and energy sources for microheterotrophs in both freshwater and marine ecosystems and contribute essentially to the bacterial production (Jørgensen \& Jensen 1994, Hanisch et al. 1996, Rich et al. 1996).

- Present address: College of Marine Studies, University of Delaware, Lewes, Delaware 19958, USA.

E-mail: bmeon@udel.edu
Despite the well-recognized importance of DCHO in the aquatic carbon food web, there is surprisingly little information about the in situ composition, concentrations and dynamics of the different fractions of the $\mathrm{DCHO}$, such as the dissolved free carbohydrates (DFCHO) and the dissolved combined carbohydrates (DCCHO) that include oligo- and polysaccharides.

The determination of DCHO by colorimetric methods provides no information on the molecular level and is particularly sensitive to errors caused by the low specificity, the different sensitivities for individual sug- 
ars (Stabel 1977a, de Haan \& de Boer 1979, Senior \& Chevolot 1991) and the possibility that bound or colloid-associated molecules that are not as easily available for microorganisms are also included (Gocke et al. 1981, Carlson et al. 1985). Gas chromatography (GC) (Stabel 1977b, Münster 1984, Münster \& Chróst 1990) and the recently introduced high performance liquid chromatography with pulsed amperometric detection (HPLC-PAD) (Johnson \& LaCourse 1990, Mopper et al 1992, Jørgensen \& Jensen 1994, Rich et al. 1996, Borch \& Kirchman 1997) allow the determination of both the individual sugars that comprise DFCHO and DCCHO after hydrolysis. Concentrations of individual free sugars measured by HPLC-PAD were typically reported to be $<50 \mathrm{nM}$ whereas concentrations measured by GC showed larger variations and, in the case of glucose, reached values of $>2.5 \mu \mathrm{M}$ (Münster \& Chróst 1990). This indicates that, in addition to different sampling locations, methodological differences may have influenced the values obtained.

Few data are available on the occurrence and molecular composition of oligosaccharides in aquatic environments and even less on their utilization by microheterotrophic organisms although uptake of oligosaccharides up to a degree of polymerization of 5 (Strobel et al. 1995) or 7 (Ferenci 1980) have been reported for laboratory cultures of Clostridium thermocellum and Escherichia coli, respectively. In water samples from the northern North Pacific and the Bering Sea the concentrations of total oligosaccharides (glucose equivalents) ranged from 36 to $61 \mathrm{nmol} \mathrm{l}^{-1}$ (Sakugawa \& Handa 1985), sucrose, trehalose, melibiose and 4 other tentatively characterized disaccharides consisting of hexoses being the dominant components. Sucrose was shown to be a component of the free sugars in the Biscayne Bay, Florida (Mopper et al. 1992). According to the authors some unidentified peaks eluting near sucrose indicated the presence of additional di- and trisaccharides. A recent study by Aluwihare et al. (1997) showed that closely related acyl-oligosaccharides of biotic origin contributed up to $20 \%$ of total DOC in surface sea water. High concentrations of oligosaccharides in seawater sediments have been determined by electrospray mass spectrometry (Hulthe et al. 1997). In lakewater melibiose, cellobiose and sucrose have been repeatedly identified in concentrations between 3 and $220 \mathrm{nM}$ (Münster 1984, Jørgensen 1990, Jørgensen \& Jensen 1994), and maltose, maltotriose and maltotetraose have been determined as exudation products of phytoplankton in a eutrophic lake (Jüttner \& Matuschek 1978). The lack of information on oligosaccharides is in contradiction to their importance as substrates for microheterotrophs.

In the present study we introduce thermospray mass spectrometry in combination with HPLC as a suitable method to determine quantitatively dissolved monoand oligosaccharides in lakewater. Using this technique we measured concentrations of mono- and oligosaccharides in a eutrophic lake throughout the year and determined the short-term variability of sugar concentrations. Care was taken to minimize the impact of the filtration process on the sugar concentrations of the filtrate by disintegration of cells. Hollow-fibres were a superior technique for this purpose. In situ experiments with oligosaccharides were used to learn about the so-far neglected degradation and uptake of oligosaccharides in lakewater.

\section{MATERIALS AND METHODS}

Study site. Lake $\mathrm{Au}\left(47^{\circ} 15^{\prime} \mathrm{N}, 8^{\circ} 39^{\prime} \mathrm{E}\right.$, area: $45000 \mathrm{~m}^{2}$ ) is a shallow, polymictic eutrophic lake with a maximum depth of $4.2 \mathrm{~m}$ and is connected with Lake Zurich (Switzerland) through a $60 \mathrm{~m}$ long canal. During the sampling period the concentrations of inorganic phosphorus (soluble reactive phosphorus, SRP: $<0.03$ to $6.6 \mu \mathrm{M}), \mathrm{NH}_{4}{ }^{+}(0.12$ to $91 \mu \mathrm{M})$ and biomass related parameters (chl a: 3 to $>300 \mu \mathrm{g} \mathrm{l}^{-1}$; particulate organic carbon, POC: 1.3 to $10.2 \mathrm{mg} \mathrm{Cl}^{-1}$; total phosphorus, TP: 1.4 to $17.5 \mu \mathrm{M}$ ) showed large variations with depth (Meon 1997). The rapid and frequent change of these parameters is the result of inputs of nutrients from farmland (vineyards and pastures), mixing of nutrient-rich hypolimnetic water and epilimnetic water, and the resuspension of particles from the sediment caused by repeated wind-induced turnovers of the whole water body that occurred even in summer. Under stable weather conditions an anoxic hypolimnion was quickly established and hydrogen sulphide production was then observed below $2.5 \mathrm{~m}$ from May through October. The Secchi depths varied between 0.8 and $1.7 \mathrm{~m}$.

Sampling procedure and separation of particulate matter. Water samples for the determination of dissolved sugars were collected at biweekly or monthly intervals between July 1994 and July 1995 from depths of 0.5 and $3.25 \mathrm{~m}$ of Lake Au using a battery-powered peristaltic pump (Portable Masterflex 7533-40, $12 \mathrm{~V}$, $28 \mathrm{~W}$ ) equipped with a short piece of silicon tubing for the head of the pump and a less extensible Tygon tubing that was submersed into the water. As described previously (Jüttner et al. 1997), a hollow-fibre module (KrosFlow II Modul K22M-100-01N, $0.2 \mu \mathrm{m}$ pore size, Microgon, Laguna Hills, CA, USA) was in line with this tubing and enabled the gentle separation of particulate and dissolved matter of the water within seconds after removal from its origin. Water samples were taken between 10:00 and 11:00 $\mathrm{h}$ to minimize diel variations in the parameters that are effected by the daytime and to 
allow comparisons of the sugar concentrations between the different sampling days throughout the year. Immediately after filtration, a defined amount of ${ }^{13} \mathrm{C} 6$-glucose (final concentration between 26 and $120 \mathrm{nM}$ ) was added as an internal standard to $1.0 \mathrm{l}$ of the filtrate.

During field work and transport to the laboratory, the filtrate was stored in acid washed and prerinsed glass bottles (Duran, Schott) that were placed in an icecooled styrofoam box. In the laboratory the water samples were kept frozen in these bottles $\left(-20^{\circ} \mathrm{C}\right)$ until further treatment.

A TOC analyzer (Shimadzu, model 5000) was used for DOC determination of filtered lakewater. Before injection the samples were acidified with $2 \mathrm{M} \mathrm{HCl}$ to $\mathrm{pH} 2$. Injections (usually between 3 to 5) were repeated until the coefficient of variation (SE/mean) was $<0.02$.

To overcome experimental errors caused by patchiness of lakewater, a $110 \mathrm{l}$ glass cylinder $(0.45 \mathrm{~m}$ i.d., $0.8 \mathrm{~m}$ height) with a valve at the bottom and an open top was exposed in situ. The vessel was filled with lakewater and stabilized by styrofoam buoys. To fill the glass vessel, the inlet valve at the bottom was opened and the vessel was smoothly pressed down into the lakewater. By this procedure after closing of the inlet valve the content of the vessel represented the upper $0.8 \mathrm{~m}$ water column of Lake Au. To obtain information on short-term variations and concentrations of monoand oligosaccharides, 1.01 water samples of this mesocosm were taken by the above described hollow-fibre filtration device between 10:30 and 13:00 h, initially in $15 \mathrm{~min}$, later in $30 \mathrm{~min}$ time intervals.

In situ incubation experiments. From August through October 1995 incubation experiments in microcosms were performed to study the in situ decrease of different sugars in lakewater. Tedlar bags $(5.0 \mathrm{l}$, Bohlender, Lauda, Germany) were filled with lakewater pumped from a depth of $1 \mathrm{~m}$. Lakewater of the different Tedlar bags was supplemented with maltose (final concentration $2.75 \mu \mathrm{M}$ ), maltotriose (final concentration 1 and $1.3 \mu \mathrm{M}$, respectively), maltotetraose (final concentration $1.3 \mu \mathrm{M}$ ) and 3-O- $\beta$-galactopyranosyl-D-arabinose (GPA, final concentration $1.3 \mu \mathrm{M}$ ). The Tedlar bags were incubated at $1 \mathrm{~m}$ depths positioned horizontally on Plexiglas trays. Over a time period of 48 to $52 \mathrm{~h}, 150 \mathrm{ml} \mathrm{sam-}$ ples were taken out of the Tedlar bags with a plastic syringe and gently filtered through MediaKap-2 filters (0.2 $\mathrm{MM}$ pore size, Microgon), which had been flushed previously with deionised, UV-treated water. The first $50 \mathrm{ml}$ of the filtrate was discarded and the remaining $100 \mathrm{ml}$ was supplemented with internal standards $\left({ }^{13} \mathrm{C} 6\right.$ glucose and GPA) to give concentrations that were equimolar to those of the sugars added at the beginning of the incubation experiment.

Chlorophyll $a$ and bacterial counts. On the boat, directly after removal from the Tedlar bags, 25 to
$50 \mathrm{ml}$ samples of lakewater were filtered on GF6-filters (Schleicher \& Schuell) with a Nalgene bottle top filter unit attached to a hand vacuum pump. The filters were then wrapped in aluminium foil and stored in liquid nitrogen. Pigments were extracted with acetone/water $(90 / 10 ; \mathrm{v} / \mathrm{v})$ according to a procedure by Schanz (1982) and chlorophyll a was determined fluorometrically (Hitachi F-2000) using an excitation wavelength of $430 \mathrm{~nm}$ and an emission wavelength of $670 \mathrm{~nm}$. Bacterial numbers were counted by epifluorescence microscopy of glutardialdehyde fixed samples ( $2 \%$ final concentration) after 4',6-diamidino- 2 phenylindole staining according to Güde et al. (1985) but using Anodisc 25 filters $(0.2 \mu \mathrm{m}$ pore size, Whatman). Higher cell counts were obtained with these filters than with polycarbonate membranes (Jones et al. 1989). The coefficient of variation ranged between 0.08 and 0.24

Analysis of sugars by liquid chromatography-thermospray mass spectrometry (LC-TSMS). The sugars of 500 to $1000 \mathrm{ml}$ filtered lakewater $(50$ to $100 \mathrm{ml}$ for incubation experiments) were concentrated by freeze drying $\left(10^{-1} \mathrm{mbar}\right.$, plate heated at $\left.30^{\circ} \mathrm{C}\right)$. To accelerate the time-consuming lyophilisation process, the samples were divided into several $150 \mathrm{ml}$ plastic beakers to increase the surface of the sample and decrease the sublimation time. The residues were transferred to a centrifuge tube. To avoid any loss caused by residues remaining on the walls and the bottom of the plastic beakers, these were washed with $4 \mathrm{ml}$ deionised UVtreated water. This water was added to the freeze dried residue in the centrifuge tube for extraction of the soluble sugar fraction. To improve the dissolution of the concentrated substances, the centrifuge tube was sonicated for $2 \mathrm{~s}$ and vortexed for $2 \mathrm{~min}$. After centrifugation for $5 \mathrm{~min}(2700 \times g)$ the aqueous supernatants were evaporated in reaction vials $(1 \mathrm{ml}$ conic ampoules) at $40^{\circ} \mathrm{C}$ using a SpeedVac vacuum concentrator. For acetylation of the residues, 100 to $250 \mu \mathrm{l}$ acetic anhydride and an equal volume of pyridine were added. After addition of the reagents, the vials were flushed with nitrogen, sealed with Teflon lined rubber discs and incubated overnight at ambient temperature. Evaporation of the derivation reagents was performed in a nitrogen gas stream. The acetylated sugars were extracted 3 times each with $500 \mu \mathrm{CH}_{2} \mathrm{Cl}_{2}$ The combined $\mathrm{CH}_{2} \mathrm{Cl}_{2}$ extracts evaporated with a nitrogen gas stream were stored in a freezer until analysis that was performed within a few days.

Analysis of the acetylated sugars (except incubation experiments with maltotetraose and GPA) was carried out using liquid chromatography in combination with a thermospray mass spectrometer (VT 201, Vestec corporation, USA) as detection system. A C18-reversed phase column (Spherisorb ODS, $250 \times 4.6 \mathrm{~mm}, 5 \mu \mathrm{m}$ 
Table 1. Ion structure, quasi molecular ions, recorded mass range and ions used for the quantification of acetylated sugars of lake water by HPLC-TSMS. Sodium adduct ions refer to the application of ESMS as detection method

\begin{tabular}{|c|c|c|c|c|}
\hline Compound & Ion structure & $m / z$ & Mass range $(m / z)$ & Quantification $(\mathrm{m} / \mathrm{z})$ \\
\hline${ }^{13} \mathrm{C} 6$-glucose & $\begin{array}{l}{\left[\mathrm{M}+\mathrm{NH}_{4}\right]^{+}} \\
{\left[\mathrm{M}-\mathrm{OAC}^{+}\right.}\end{array}$ & $\begin{array}{l}414 \\
337\end{array}$ & $\begin{array}{l}413-415 \\
335-337\end{array}$ & $337 ; 414$ \\
\hline Hexoses $^{a}$ & $\begin{array}{l}{\left[\mathrm{M}+\mathrm{NH}_{4}\right]^{+}} \\
{\left[\mathrm{M}-\mathrm{OAC}^{+}\right.}\end{array}$ & $\begin{array}{l}408 \\
331\end{array}$ & $\begin{array}{l}407-409 \\
330-332\end{array}$ & $331 ; 408$ \\
\hline Disaccharides $^{\alpha}$ & {$\left[\mathrm{M}+\mathrm{NH}_{4}\right]^{+}$} & 696 & $695-697$ & $696 ; 697$ \\
\hline Trisaccharides ${ }^{\alpha}$ & {$\left[\mathrm{M}+\mathrm{NH}_{4}\right]^{+}$} & 984 & $983-985$ & $984 ; 985$ \\
\hline Tetrasaccharides $^{a}$ & $\begin{array}{l}{\left[\mathrm{M}+\mathrm{NH}_{4}\right]^{+}} \\
{[\mathrm{M}+\mathrm{Na}]^{+}}\end{array}$ & $\begin{array}{l}1272 \\
1277\end{array}$ & $\begin{array}{l}1271-1273 \\
1276-1279\end{array}$ & $\begin{array}{c}1272 ; 1273 \\
1277\end{array}$ \\
\hline 3-O- $\beta$-galactopyranosyl-D-arabinose (GPA) & {$[\mathrm{M}+\mathrm{Na}]^{+}$} & 629 & $628-630$ & 629 \\
\hline
\end{tabular}

Bischoff Analysentechnik und -geräte, Leonberg, Germany) served as stationary phase. Before analysis the dried $\mathrm{CH}_{2} \mathrm{Cl}_{2}$ extracts were redissolved in 200 to $300 \mu \mathrm{l}$ of $0.05 \mathrm{M}$ methanolic ammonium acetate $/ 0.05 \mathrm{M}$ aqueous ammonium acetate $(45 / 55 ; \mathrm{v} / \mathrm{v})$ and $100 \mu \mathrm{l}$ was injected onto the HPLC system. The solvent gradient supplied by a pulse-damped HPLC pump (IRIS 322, Kontron Instruments) changed linearly from $0.05 \mathrm{M}$ methanolic ammonium acetate/0.05 $\mathrm{M}$ aqueous ammonium acetate $(45 / 55 ; \mathrm{v} / \mathrm{v})$ to $0.05 \mathrm{M}$ methanolic

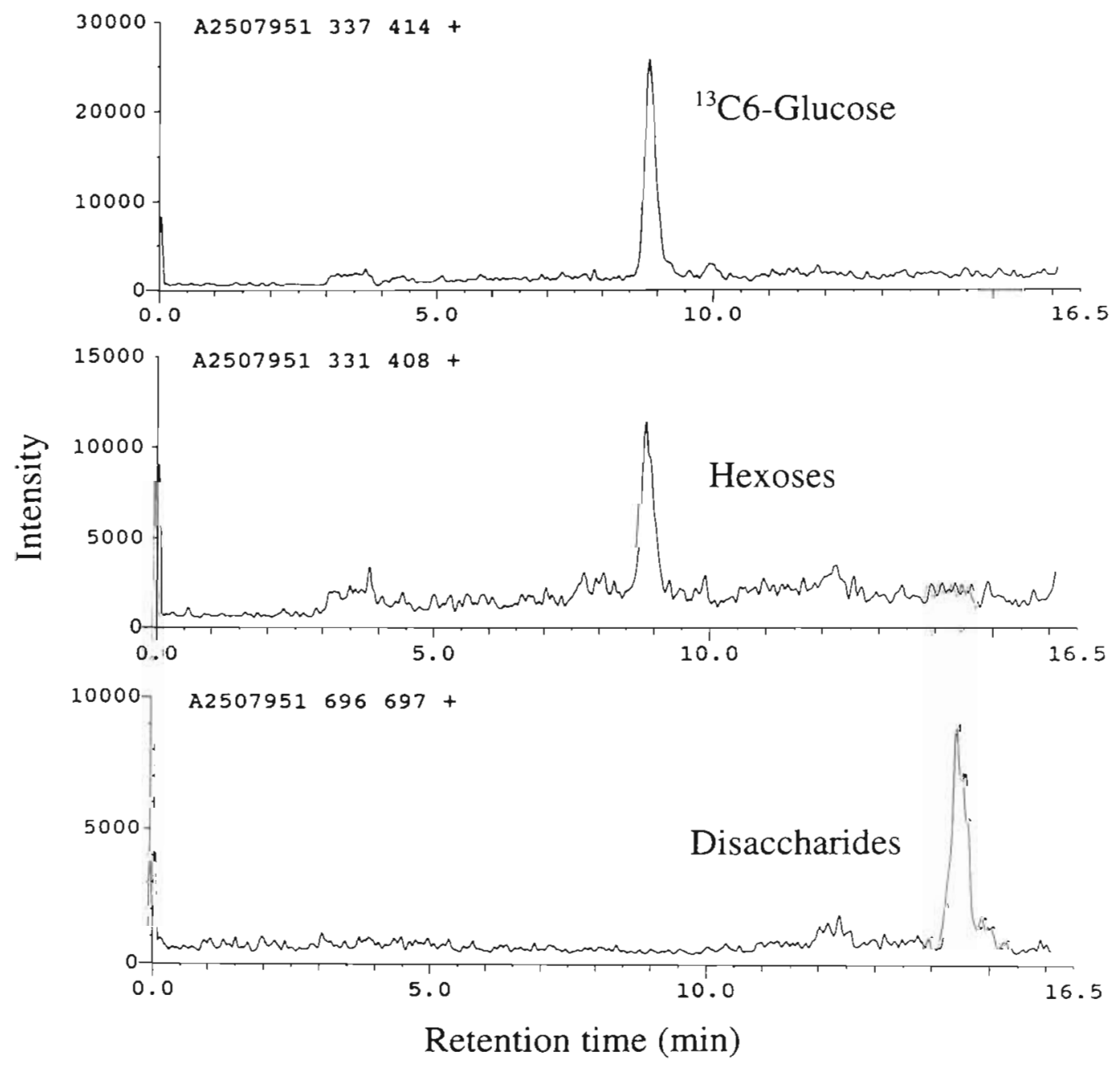

Fig. 1. Extracted ion chromatograms of a lakewater sample (Lake Au). ${ }^{13} \mathrm{C} 6$-Glucose (28 nM) was added as an internal standard immediately after separation of the dissolved fraction from the particulate matter on the boat. Hexose and disaccharide concentrations were 12 and $14 \mathrm{nM}$, respectively 
ammonium acetate/0.05 $\mathrm{M}$ aqueous ammonium acetate $(70 / 30 ; \mathrm{v} / \mathrm{v})$ within $13 \mathrm{~min}$ and subsequent isocratic separation for $20 \mathrm{~min}$. The flow rate was $1 \mathrm{ml}$ $\min ^{-1}$. The application of the described gradient program allowed the separation of mono- to hexasaccharide fractions since isomers and anomers coeluted. Online detection of the separated sugars by the mass spectrometer was done in the multiple ion selection (MIS) mode recording the positive masses for acetylated mono- and oligosaccharides as listed in Table 1. Standard parameters during mass acquisition were as follows: block temperature, $300^{\circ} \mathrm{C}$; tip heater temperature, $300^{\circ} \mathrm{C}$; vaporizer, 150 to $170^{\circ} \mathrm{C}$; filament, $100 \mu \mathrm{A}$. The upper mass detection limit $(\mathrm{m} / z$ 2000) theoretically allowed the analysis of oligosaccharides up to a polymerization degree of 6 . Areas of the ions $\mathrm{m} / z 337$ and $\mathrm{m} / z 414$ of the internal standard $\left({ }^{13} \mathrm{C} 6\right.$-glucose) were used as the basis for quantitative hexose analysis. The lower sensitivity of the mass acquisition system for oligosaccharides as compared to the ${ }^{13} \mathrm{C} 6$-glucose was corrected by response factors, determined by the analysis of equimolar amounts of acetylated mono- and oligosaccharide standards. Extracted ion chromatograms of a lakewater sample as used for quantitative analysis are given in Fig. 1. The linearity of the detector response was tested over 2 orders of magnitude with underivatized glucose (1.7 to $170 \mathrm{nmol}$ ) using $55 \mathrm{nmol}{ }^{13} \mathrm{C} 6$-glucose as internal standard $\left(\mathrm{r}^{2}=0.996\right.$, coefficient of variation between 0.01 and 0.015$)$. The detection limit was approximately $1 \mathrm{nM}$ for aldo-/ketohexoses and disaccharides and $2 \mathrm{nM}$ for tri- and tetrasaccharides when 500 to $1000 \mathrm{ml}$ of lakewater was concentrated. When the sample was reduced to 50 to $100 \mathrm{ml}$, the detection limit was between 10 to $20 \mathrm{nM}$.

Sugar analysis by electrospray mass spectrometry (ESMS). Samples of the incubation experiments with GPA and maltotetraose were analysed by ESMS without previous separation using an electrospray source of the same mass spectrometer. The equipment was developed and described by Allen \& Vestal (1992). A syringe infusion pump (model 341B, Sage Instruments, Boston, USA), equipped with a gas-tight $250 \mu$ syringe (Hamilton, Reno, USA) delivered a continuous, pulseless solvent flow (methanol/0.005 $\mathrm{M}$ aqueous NaOAC

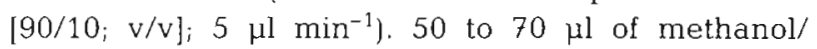
$0.005 \mathrm{M}$ aqueous $\mathrm{NaOAc}(90 / 10 ; \mathrm{v} / \mathrm{v})$ was added to the evaporated $\mathrm{CH}_{2} \mathrm{Cl}_{2}$ extracts of the acetylated sugars, and $25 \mu \mathrm{l}$ was injected on a $20 \mu l$ loop. Typical parameters during mass acquisition were as follows: nozzle, $100 \mathrm{~V}$; needle, 1.7 to $1.8 \mathrm{kV}$; block, $240^{\circ} \mathrm{C}_{\mathrm{i}}$ chamber, $55^{\circ} \mathrm{C}_{i}$ repeller, $29 \mathrm{~V}$. For quantification, the sodium adduct ions of the acetylated sugars (see Table 1) were averaged over a scan period of 1 to $2 \mathrm{~min}$ and peak heights relative to the internal standards were used to calculate the sugar concentrations.
The advantages of ESMS are that signals can be averaged over a relatively long time period due to the low flow rates and that a preseparation of the sugars by a HPLC column is not necessary. An increase in sensitivity as compared to thermospray mass spectrometry was not found and the maintenance of suitable spray conditions turned out to be very difficult mainly because some internal parts of the electrospray source were soon contaminated after application of lakewater samples.

\section{RESULTS}

\section{Annual, diel and short-term dynamics of in situ sugar concentrations in Lake Au}

Concentrations of aldo-/ketohexoses and oligosaccharides in Lake Au for the period between July 1994 and July 1995 are presented in Fig. 2. Seasonal trends in the sugar concentrations were not apparent. During the sampling period, dissolved aldo-/ketohexoses with concentrations between $<1$ and $48 \mathrm{nM}$ (mean: $13 \mathrm{nM}$ )
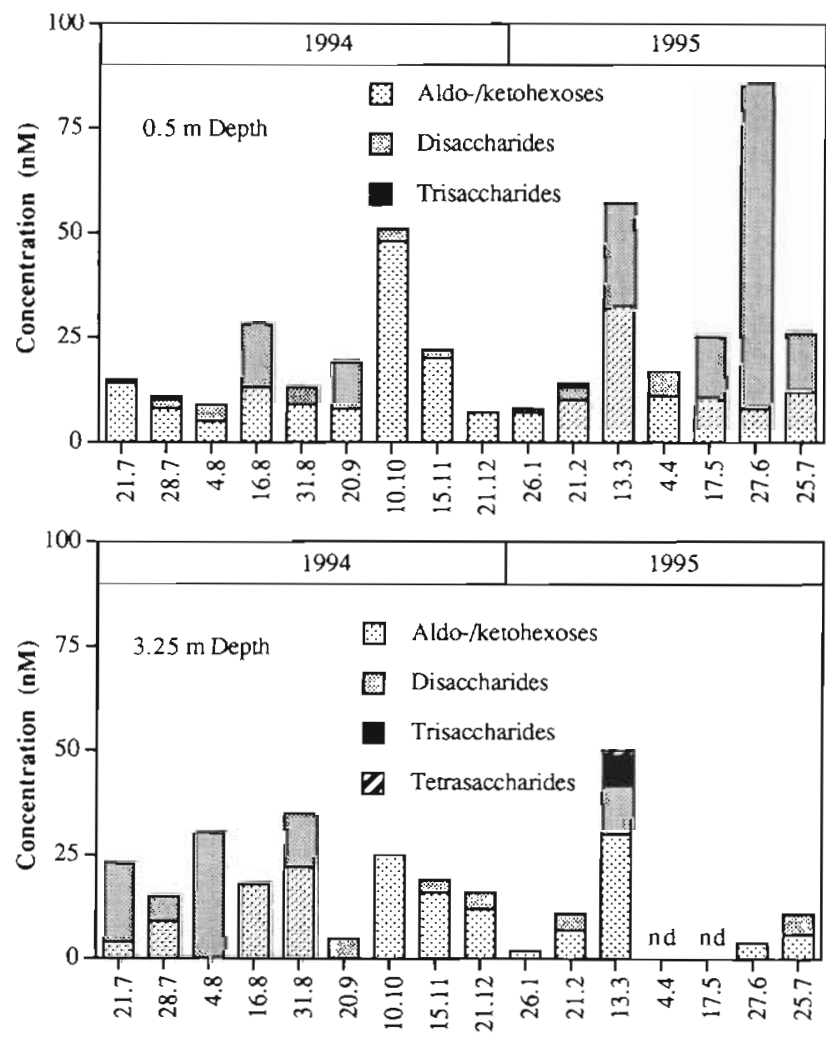

Sampling date

Fig. 2. Concentrations of aldo-/ketohexoses, di-, tri- and tetrasaccharides (aldo- and ketohexoses) in Lake Au between July 1994 and July 1995 at depths of 0.5 and $3.25 \mathrm{~m}$. nd: not determined 

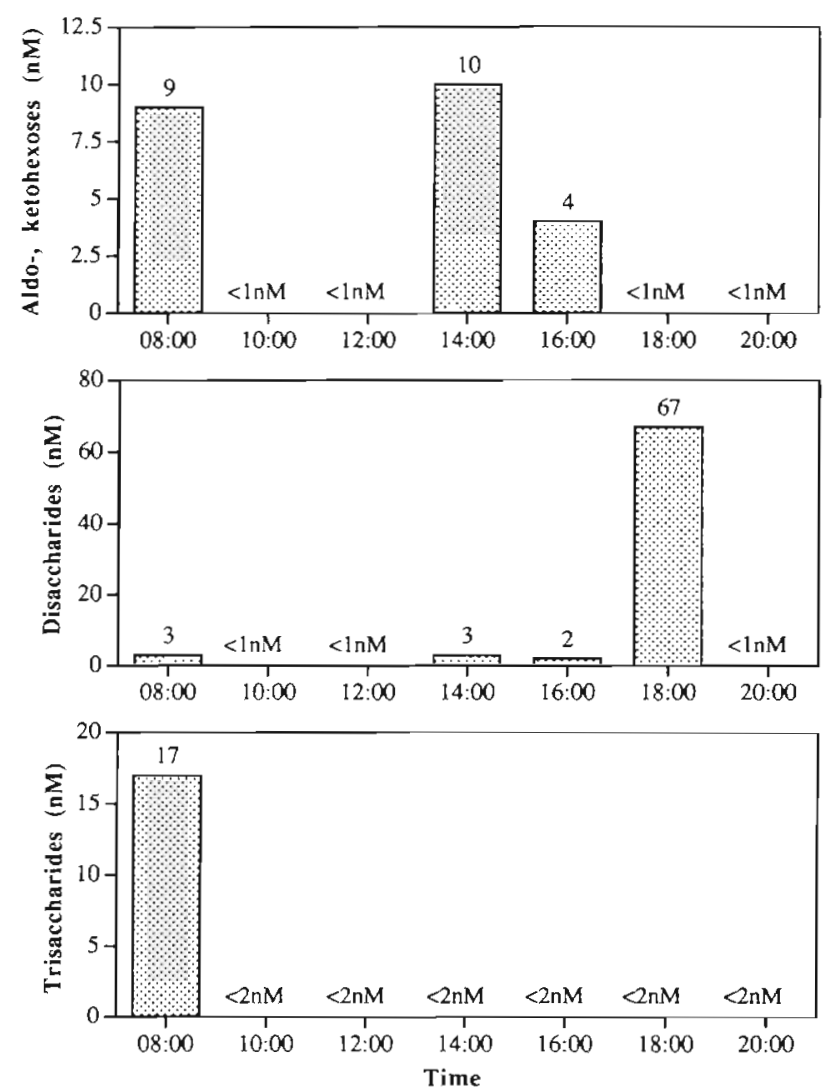

Fig. 3. Diurnal dynamics of aldo-/ketohexoses, di- and trisaccharides at 1 m depth in Lake Au on 22 April 1994

and disaccharides with concentrations between $<1$ and $77 \mathrm{nM}$ (mean: $9 \mathrm{nM}$ ) represented the dominant sugar fractions at 2 depths ( 0.5 and $3.25 \mathrm{~m}$ ). Tri- and tetrasaccharides were below the detection limit of $2 \mathrm{nM}$ on most sampling dates. Penta- and hexasaccharides were not detected in a single case. The total of monoand oligosaccharides at different sampling dates was typically below $30 \mathrm{nM}$. A maximum value ( $85 \mathrm{nM}$ ) was observed on 27 June 1995 at $0.5 \mathrm{~m}$ depth. On several sampling dates, the concentration of disaccharides exceeded the concentration of aldo-/ketohexoses, i.e. on 27 June 1995 (0.5 m depth, $69 \mathrm{nM}$ ) and on 21 July 1994 (3.25 $\mathrm{m}$ depth, $15 \mathrm{nM}$ ). The total carbon content of the detected mono- and oligosaccharides on the different sampling days represented 0.003 to $0.3 \%$ of the DOC.

On 22 April 1994 the diel variation of the concentrations of monosaccharides, disaccharides and trisaccharides was analysed. During the $12 \mathrm{~h}$ sampling period marked concentration differences were observed (Fig. 3). Most concentrations were below the detection limit. Interestingly, transient pulses of sugar concentrations occurred, such as the increase of the disaccharide fraction from $2 \mathrm{nM}(16: 00 \mathrm{~h})$ to $67 \mathrm{nM}(18: 00 \mathrm{~h})$ and a subsequent decrease to $<1 \mathrm{nM}$ at 20:00 h. A corre-
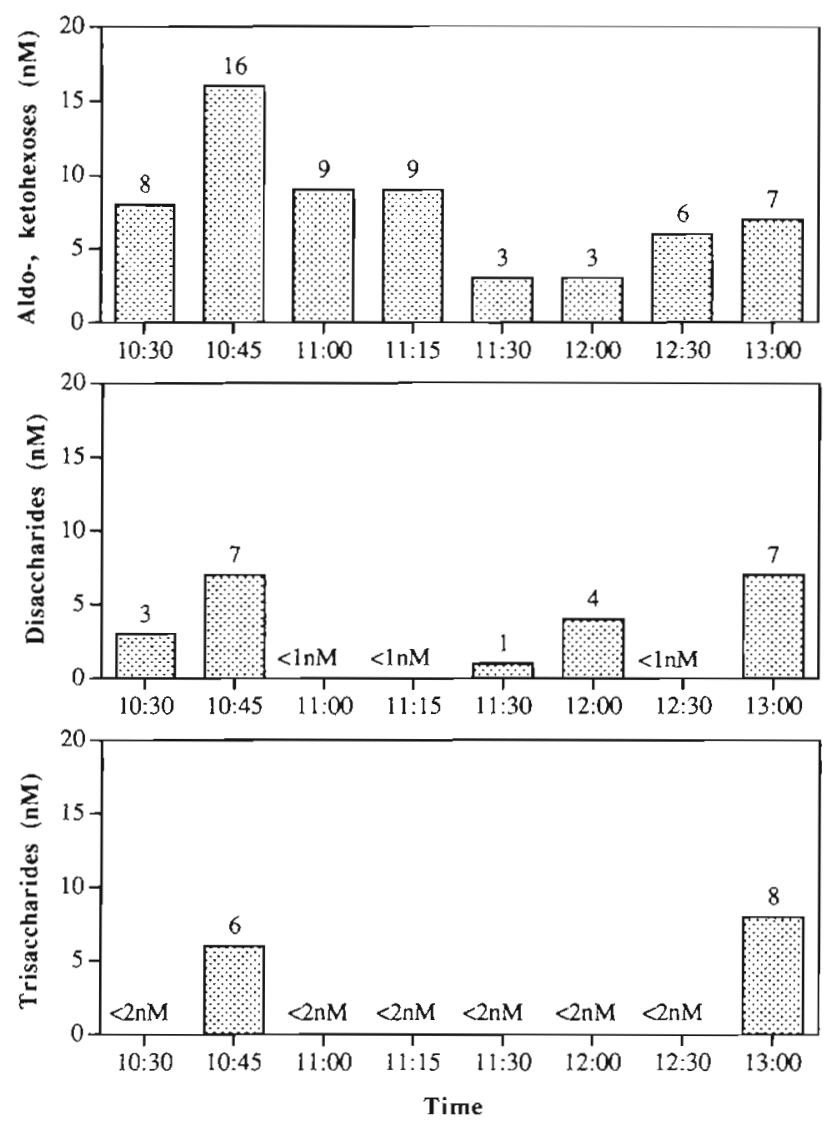

Fig. 4. Short-term dynamics of aldo-/ketohexoses, di- and trisaccharides in an in situ exposed mesocosm filled with 1101 of lakewater from Lake Au on 4 April 1995

sponding increase of aldo-/ketohexoses between 18:00 and 20:00 h was not observed.

To rule out patchy distribution of sugars in the lake caused by water currents or drift of the boat during the sampling period, which might actually be the reason for concentration pulses, lakewater enclosed in a $110 \mathrm{l}$ drifting mesocosm was sampled at short intervals over a time period of $2.5 \mathrm{~h}$ on 4 April 1995 (Fig. 4.). The sugar concentrations were very low, exhibiting values below $17 \mathrm{nM}$. The concentrations of the aldo-/ketohexoses changed within the sampling period to the same extent as observed in free lakewater.

\section{Incubation experiments}

Experiments in which the uptake/degradation of oligosaccharides was studied were performed in Tedlar bags which were supplied with different sugar concentrations. The dynamics of sugar concentrations and bacterial numbers during the incubation period are shown for maltose in Fig. 5, for maltotriose in Fig. 6, for maltotetraose and GPA in Fig. 7. With the exception of 

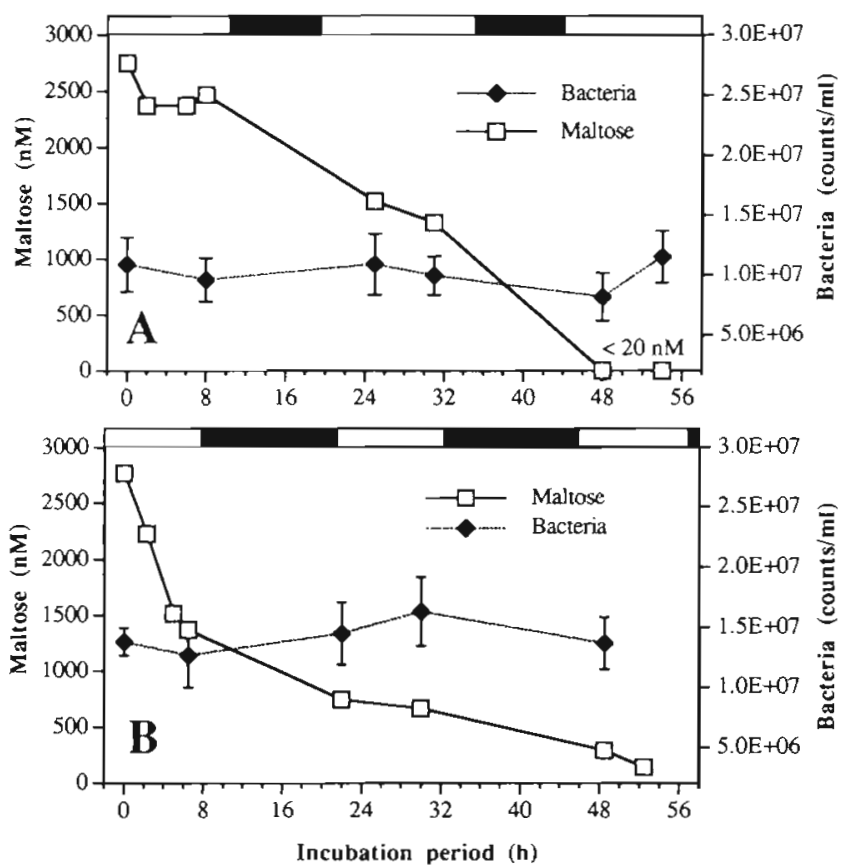

Fig. 5. Time course of the maltose concentrations and bacterial numbers in Tedlar bags exposed in situ on (A) 2 to 4 August 1995 and (B) 10 to 12 October 1995. The Tedlar bags were filled with $5 \mathrm{l}$ lakewater from $1 \mathrm{~m}$ depth of Lake Au. Maltose was added to give a final concentration of $2.75 \mu \mathrm{M}$ Black bars at the top indicate dark periods, error bars indicate $\pm 1 \mathrm{SD}$

GPA, the concentrations of the added sugars (which included the regenerated sugars) after an incubation period of 48 to $52 \mathrm{~h}$ were $<150 \mathrm{nM}$, often even close to or below the detection limit of 10 to $20 \mathrm{nM}$. Concentrations decreased immediately after the start of the incubation experiments. The shapes of the curves show an almost linear (e.g. maltotriose, Fig. $6, \mathrm{r}^{2}=0.899$ and 0.806, and maltotetraose, Fig. $7, \mathrm{r}^{2}=0.992$ ) or an exponential decline (e.g. maltose, Fig. 5, $r^{2}=0.959$ ). Light and dark periods during the experiments had no significant influence on the uptake rates. Average decrease rates, based on the concentration at the start and at the end of an incubation experiment and assuming a linear decrease were 46 and $50 \mathrm{nmol} \mathrm{l^{-1 }} \mathrm{h}^{-1}$ (6.6 and $7.2 \mu \mathrm{g} \mathrm{Cl}^{-1} \mathrm{~h}^{-1}$ ) for maltose, 30 and $27 \mathrm{nmol} \mathrm{l}^{-1}$ $\mathrm{h}^{-1}\left(6.5\right.$ and $\left.5.9 \mu \mathrm{g} \mathrm{Cl}^{-1} \mathrm{~h}^{-1}\right)$ for maltotriose and $28 \mathrm{nmol}$ $\mathrm{l}^{-1} \mathrm{~h}^{-1}\left(8.0 \mu \mathrm{g} \mathrm{C}^{-1} \mathrm{~h}^{-1}\right)$ for maltotetraose. In contrast the concentration of GPA after $48 \mathrm{~h}(908 \mathrm{nM})$ still represented a significant portion $(69.8 \%)$ of the $1300 \mathrm{nM}$ added at the beginning of the experiment. Furthermore, for this compound an induction period of at least $29 \mathrm{~h}$ was necessary before a decrease was detectable. The average decrease rate for GPA was $8.2 \mathrm{nmol} \mathrm{l}^{-1} \mathrm{~h}^{-1}$ (1.1 $\left.\mathrm{gg} \mathrm{C}^{-1} \mathrm{~h}^{-1}\right)$.

The decrease of sugars in the Tedlar bags was not accompanied by a significant increase in bacterial

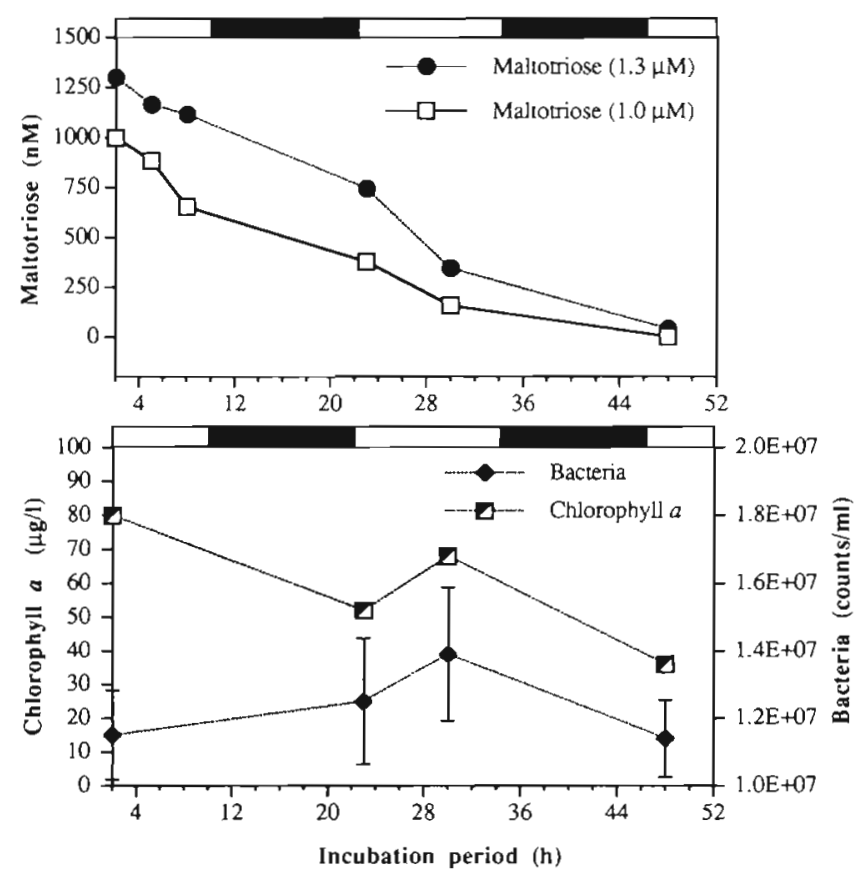

Fig. 6. Time course of the maltotriose concentrations in 2 in situ exposed Tedlar bags each filled with $5 \mathrm{l}$ lakewater from $1 \mathrm{~m}$ depth of Lake Au after addition of maltotriose to give final concentrations of 1 and $1.3 \mu \mathrm{M}$, respectively. Bacterial numbers and chlorophyll a concentrations are given for the Tedlar bag incubated with $1.0 \mu \mathrm{M}$ maltotriose as start concentration. Incubation experiments were performed on 6 to 8 September 1995. Black bars at the top indicate dark periods, error bars indicate $\pm 1 \mathrm{SD}$

numbers. Only in the experiment in which maltotetraose was added (Fig. 7), did bacterial numbers increase significantly ( $t$-test, $p<0.001$ ) from $1.4 \times 10^{7}$ to $2.4 \times 10^{7}$ cells $\mathrm{ml}^{-1}$. The sedimentation rate of the particulate matter in the Tedlar bags within an incubation period was rather low. After $48 \mathrm{~h}$ almost $50 \%$ of the chlorophyll a bound in particles was still suspended (Fig. 6). In contrast to glass vessels the deformable bags facilitate mixing conditions and thus allow particles to remain much longer in suspension.

\section{DISCUSSION}

\section{Identification and quantification of dissolved sugars in lakewater by LC-TSMS and ESMS}

Reversed phase HPLC has been demonstrated as a suitable separation technique for acetylated monoand oligosaccharides (Wells \& Lester 1979). Information in addition to retention times has become available by hyphenated HPLC systems. Thermospray mass spectrometry (Vestal 1984) is one of these detection systems that have recently been applied to analyse 


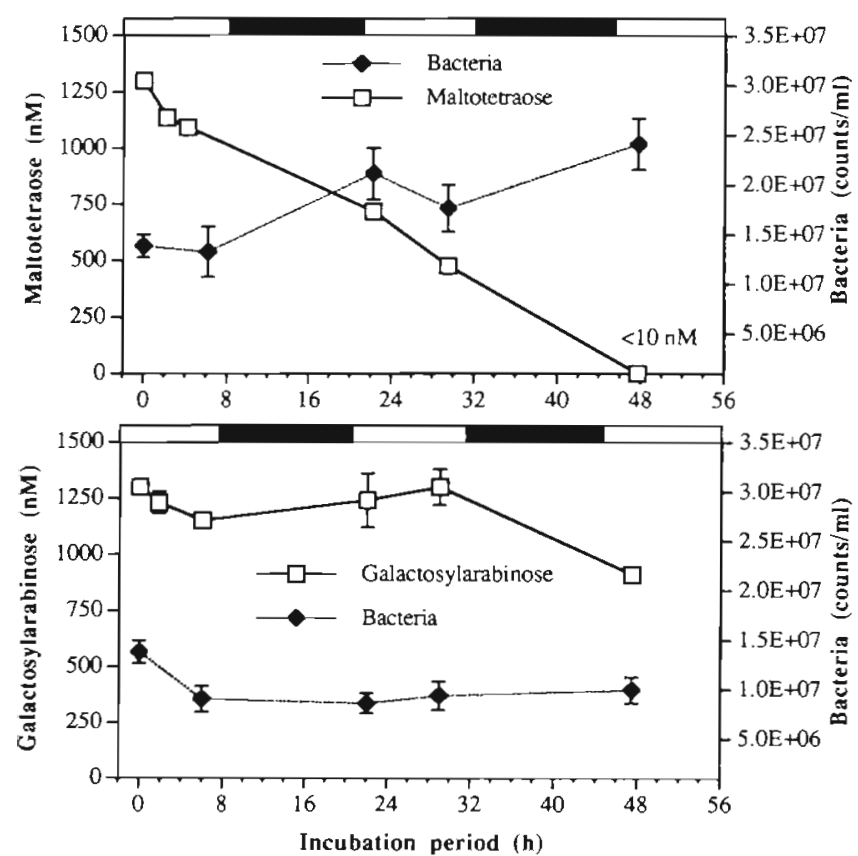

Fig. 7. Tirne course of the maltotetraose concentrations and bacterial numbers, and 3-O- $\beta$-D-galactopyranosyl-D-arabinose concentrations and bacterial numbers in Tedlar bags, exposed in situ on 10 to 12 October 1995. The Tedlar bags were filled with 51 of lakewater from $1 \mathrm{~m}$ depth in Lake Au. Sugars were added to give the final concentration of $1.3 \mu \mathrm{M}$. Black bars at the top indicate dark periods, error bars indicate $\pm 1 \mathrm{SD}$

mono- and oligosaccharides in combination with reversed phase and high performance anion exchange chromatography (Simpson et al. 1990, Niessen et al. 1992a, 1992b, Van der Hoeven et al. 1992). These authors used commercially available sugars or enzyme digests of cell wall components which are available in large amounts. However, the analysis of sugars in lakewater is far more difficult and challenging because both the low concentrations and the complexity of compounds have to be overcome. To our knowledge the present study is the first to use LC-TSMS to identify and quantify mono- and oligosaccharides in lakewater.

The application of mass spectrometry as a detection system makes the qualitative and quantitative analysis of sugars in the most complex water samples much more reliable than retention-time-based GC and HPLC methods and in particular as compared to colorimetric assays. Non-carbohydrate compounds that are always present in the samples obtained from water are not very likely to interfere with ions for sugars. In addition, the application of a stable isotope-labelled sugar, added immediately after sampling, compensated for any loss of compound during sample preparations and fluctuations and sensitivity drift of analytic equipment during analyses over long periods. This technique also offers alternatives to the environmentally more critical application of radioactive tracers. The major drawback of the method that restricted the sample number turned out to be the concentration step necessary to reach the detection limit of the thermospray mass spectrometer.

Lyophilisation, the concentration procedure used in this study, is generally believed to be gentle and to deliver high recovery rates (Abbt-Braun et al. 1991). However, recovery experiments conducted with ${ }^{13} \mathrm{C} 6$ glucose added to filtered lakewater and UV-treated deionised water showed significant losses up to $70 \%$. Another negative effect was caused by the matrix of the non-carbohydrates in the samples which resulted in a further decrease of sensitivity of about $20 \%$ (data not shown). Losses of dissolved sugars by freeze drying have been reported before by several authors (Mopper 1977. Dawson \& Mopper 1978, Pakulski \& Benner 1992) while Jørgensen (1990) observed no losses.

\section{Concentrations and dynamics of mono- and oligosaccharides in Lake Au}

The concentrations of monosaccharides in Lake Au were typically in the lower nanomolar range or below the detection limit of $1 \mathrm{nM}$ and are significantly lower than most published data (see Table 2). The comparison of analyses reported in the literature is difficult, in some cases impossible, because the applied technology has a major impact on the composition of the sugar species which are considered to compose the DFCHO fraction. In some cases pentoses (i.e. Münster 1984, Jørgensen \& Jensen 1994), deoxipentoses, deoxihexoses (Gremm \& Kaplan 1997) and disaccharides (Jørgensen \& Jensen 1994) are included, in other studies these are missing. As a consensus group glucose, galactose, mannose and fructose can be taken, which frequently have been reported as major components of DFCHO in freshwater and sea water (Sakugawa \& Handa 1985, Jørgensen 1990, Jørgensen \& Jensen 1994, Rich et al. 1996) and which were also analysed by LC-TSMS in this study. Taking these differences into account, the concentration ranges observed in Lake $\mathrm{Au}$ are still at the lower edge of the reported measurements. This is also true for the total carbon content of the detected sugars that accounted only for 0.003 to $0.3 \%$ of the DOC in Lake Au, whereas in other studies DFCHO contributed from 0.08 to $13.2 \%$ to the DOC (Burney \& Sieburth 1977, Mopper 1977, Burney et al. 1979, Münster \& Albrecht 1994).

The major source of error leading to an overestimation of DFCHO in lakewater is the disintegration of delicate cells and breakage of filaments during the filtration process that is necessary to separate the 
Table 2. Concentrations of dissolved free carbohydrates (DFCHO, glucose units) reported for various freshwater and marine water ecosystems

\begin{tabular}{|c|c|c|c|c|}
\hline \multirow[t]{2}{*}{ Location } & \multicolumn{2}{|c|}{$\mathrm{DFCHO}(\mathrm{nM})$} & \multirow[t]{2}{*}{ Method } & \multirow[t]{2}{*}{ Source } \\
\hline & Average & Range & & \\
\hline \multicolumn{5}{|l|}{ Freshwater } \\
\hline Lake Schreventeich (ultraproductive) & $71^{\circ}$ & & HPLC/colorimetric & Gocke et al. (1981) \\
\hline Lake Stocksee (eutrophic) & $100^{4}$ & & HPLC/colorimetric & Gocke et al. (1981) \\
\hline \multicolumn{5}{|l|}{ Lake Plußsee (eutrophic) } \\
\hline & & $237-409^{a}$ & $\mathrm{GC}$ & Münster (1984) \\
\hline Lake Plußsee (eutrophic) & & $10-2625^{a}$ & $\mathrm{GC}$ & Münster \& Chróst (1990) \\
\hline Lake Bagsvaerd Sø (eutrophic) & & $40-150^{b}$ & HPLC/colorimetric & Jørgensen (1990) \\
\hline Lake Furesø (mesotrophic) & & $\begin{array}{r}67-224 \\
9-49^{a}\end{array}$ & PAD-HPLC & Jørgensen \& Jensen (1994) \\
\hline White Clay Creek & & $\begin{array}{r}50-380 \\
17-80^{\mathrm{a}}\end{array}$ & PAD-HPLC & Gremm \& Kaplan (1997) \\
\hline Lake Au (eutrophic) & 13 & $<1-48^{\mathrm{e}}$ & HPLC-TSMS & This study \\
\hline \multicolumn{5}{|l|}{ Marine water } \\
\hline North Atlantic & 894 & $361-1977$ & Colorimetric (MBTH) & Burney et al. (1979) \\
\hline $\begin{array}{l}\text { Black Sea, North Sea, Baltic Sea, } \\
\text { Sargasso Sea, Harrington Sound, } \\
\text { Pacific Ocean }\end{array}$ & & $80-1420$ & HPLC & Mopper et al. (1980) \\
\hline Northern North Sea & & $167-1000$ & HPLC & Ittekkat et al. (1981) \\
\hline North Pacific, Bering Sea & & $23-555$ & GC-MS & Sakugawa \& Handa (1985) \\
\hline \multicolumn{5}{|l|}{ Elorne Estuary, Bay of Brest river } \\
\hline $\begin{array}{l}\text { Estuary } \\
\text { River }\end{array}$ & & $\begin{array}{r}1041-6250 \\
0-2500\end{array}$ & Colorimetric (MBTH) & Senior \& Chevolot (1991) \\
\hline Various locations & 93 & $<5 \rightarrow>2300$ & PAD-HPLC & Mopper et al. (1992) \\
\hline Various locations & 716 & & Colorimetric (MBTH) & Pakulski \& Benner (1994) \\
\hline $\begin{array}{c}\text { Equatorial Pacific } \\
\text { Survey cruise } 1 \\
\text { Survey cruise } 2\end{array}$ & $\begin{array}{l}81^{\mathrm{d}} \\
19^{\mathrm{d}}\end{array}$ & & PAD-HPLC & Rich et al. (1996) \\
\hline
\end{tabular}

dissolved from the particulate fraction. Phytoplankton organisms store appreciable amounts of free sugars and the release of these intracellular sugars can be sufficient to essentially increase the sugar concentrations in the aqueous phase. Fuhrman \& Bell (1985) discussed the same kind of artifacts in the analysis of dissolved free amino acids (DFAA) caused by the use of unsuitable filters. Similar doubts were expressed by Rich et al. (1996) for neutral monosaccharides based on the observation that even gentle syringe filtration of small volumes of sea water increased the glucose concentrations by a factor of 9 . Lakewater with high phytoplankton densities as analysed in the present study is particularly sensitive to filtration errors. Just a few milliliters of such lakewater is sufficient to clog a filter and to induce leakage of delicate organisms. We took particular care to rule out filtration artifacts by introducing tangential flow filtration with hollow fibres and by applying a quasi in situ separation of the DFCHO within a few seconds after removal of the water from its original location by a tube pumping device (Jüttner et al. 1997). This separation technique in combination with the selective mass spectrometric detection can explain the low concentrations of DFCHO determined in water from Lake $\mathrm{Au}$. Therefore, it is not surprising that marked increases of sugar concentrations that have been reported when phytoplankton blooms had developed or decayed (Stabel 1977b, Ittekkot et al. 1981, Chróst et al. 1989) were not observed in Lake Au. The sugar concentrations were low, independently of whether high or low phytoplankton densities (chlorophyll a concentrations up to $320 \mu \mathrm{g} \mathrm{l}^{-1}$ and Secchi depths as low as $0.8 \mathrm{~m}$ ) were present during the seasonal succession of phytoplankton. When the sugar concentrations obtained under these circumstances belong to the lowest reported, the common view that concentrations of DFCHO increase 
with the trophic level of an aquatic ecosystem should be regarded with caution.

On a diurnal time scale (4 h sampling intervals), Münster \& Chróst (1990) reported marked differences in the $\mathrm{DFCHO}$ concentrations between day and night time in Lake Plußsee. Maximum concentrations of DFCHO were observed 2 to $4 \mathrm{~h}$ after the maximum of photosynthesis of the phytoplankton, and exudation was assumed to be the major source of DFCHO. In a $24 \mathrm{~h}$ study conducted at Lake Furesø (Denmark), Jørgensen \& Jensen (1994) did not find any trends in the concentration changes of DFCHO (3 h sampling intervals). In the present study ( $2 \mathrm{~h}$ sampling intervals) the diel concentration changes of hexoses, disaccharides and trisaccharides also showed no trends but several concentration maxima occurred that reflect the high dynamics in this system. DFCHO were rapidly taken up by microorganisms resulting in a drop of the ambient sugar concentrations to below the detection limit. Initially patchy distribution of sugars in lakewater were made responsible for these fast changes during the sampling period. However, lakewater enclosed in a floating 110 l glass vessel (15 to 30 min sampling intervals) showed differences in the concentrations of mono-, di- and trisaccharides that were in the same range as in free lakewater. This observation makes patchiness as an exclusive explanation for the concentration pulses less likely. Furthermore, as the mesocosm experiment indicates, sampling intervals in the range of hours may not be sufficient to gain a satisfying temporal resolution of the concentration changes.

The diel and annual concentration changes of monoand oligosaccharides are governed by release and uptake rates for the particular compounds. The extremely low sugar concentrations found in Lake $\mathrm{Au}$ demonstrate the ability of microorganisms to use sugars efficiently in concentrations even lower than the detection limit for hexoses and oligosaccharides of 1 and $2 \mathrm{nM}$, respectively. One of the best known high affinity uptake permeases is the phosphoenolpyruvate: phosphotransferase system (PTS) (Meadow et al. 1990). According to Lengeler (1993) the PTS and bacterial binding protein dependent systems exhibit $K_{\mathrm{t}}$ values between 0.1 and $10 \mu \mathrm{M}$. These affinities are still too low to explain efficient uptake rates of sugars in Lake Au. Unfortunately most studies on the kinetics of uptake systems were performed with laboratory organisms that are not representative for aquatic micro-organisms and the high substrate concentrations applied do not reflect the in situ conditions in lakes. The kinetic approach by Azam \& Hodson (1981) using marine microbial assemblages revealed the existence of multiphasic uptake rates for glucose with $K_{\mathrm{t}}+S_{\mathrm{n}}$ values between $5 \times 10^{-9}$ and $5.9 \times 10^{-4}$. In a subsequent study, Nissen et al. (1984) demonstrated with a marine oligocarbophilic bacterium that a strain can show multiphasic uptake kinetics with $K_{\mathrm{t}}$ values for glucose from the nanomolar to the millimolar range. The aspect of multi-compound uptake has recently been studied by Egli et al. (1993) and Lendenmann et al. (1996). These authors demonstrated that the simultaneous utilization of different hexoses and pentoses lowered the residual concentrations of the individual sugars beyond the residual concentration of sugars added singly to the growth medium. The described uptake strategy for mixed sugars and the presence of multiphasic transport and uptake systems in the bacterial community of Lake Au may be important factors explaining both the low sugar concentrations and the fast decrease of transient sugar concentration peaks.

\section{In situ decrease of added oligosaccharides in Lake Au}

The addition of different oligosaccharides to in situ exposed Tedlar bags filled with lakewater was used as an experimental approach to gain information about the fate (uptake and/or enzymatic cleavage) of oligosaccharides in Lake Au. Although the concentrations of the added sugars ( 1.3 to $2.75 \mu \mathrm{M})$ exceeded the measured in situ concentrations in Lake Au by 2 orders of magnitude, they are well below or within TDCHO or DCCHO concentrations reported for aquatic environments (Münster \& Chróst 1990, Jørgensen \& Jensen 1994, Münster \& Albrecht 1994, Hanisch et al. 1996, Borch \& Kirchman 1997). Enhanced sugar concentrations are likely to occur in microenvironments, e.g. close to lysing cells or in detritus particles, macroaggregates and fecal pellets. Therefore, the added sugars may simulate sugar pulses which have been observed in Lake Au and to which microorganisms are accidentally exposed. Uptake of the unchanged molecules rather than cleavage by $\alpha$-glucosidases may account for the decrease of maltose, maltotriose and maltotetraose. One argument for such behavior is that total $\alpha$-glucosidase activities in aquatic environments are usually below $10 \mathrm{nmol}^{-1} \mathrm{~h}^{-1}$ (Münster et al. 1989, Vrba et al. 1992, Karner \& Rassoulzadegan 1995). In Lake $\mathrm{Au}$ the ectoenzymatic $\alpha$-glucosidase activity reached $16.8 \mathrm{nmol} \mathrm{l}^{-1} \mathrm{~h}^{-1}$ (data not shown). The real cleavage rates must be regarded as being much lower because these activity measurements are based on saturating substrate concentrations of up to $200 \mu \mathrm{M}$. The data show that the activities of the ectoenzyms are not sufficient to explain the average decrease rates of 27 to $50 \mathrm{nmol} \mathrm{l}^{-1} \mathrm{~h}^{-1}$ for malto-oligosaccharides observed in the water of Lake Au. In addition, cleavage products, such as glucose were not detected in the analysed lakewater samples. This was also true for the mea- 
sured diel dynamics of sugars in Lake Au, where a decrease of maltotriose and maltotetraose concentrations was never accompanied by a corresponding increase of hexoses or disaccharides. Both observations are in agreement with experiments conducted by Arnosti \& Repeta (1994) in which bacteria from anoxic marine sediments were grown on oligosaccharides (among others maltose, maltotriose, maltopentaose, maltoheptaose). Although the sugar concentrations were several hundred-fold higher than in the present study, cleavage products were not found during the course of degradation of 2 to $4 \mathrm{~d}$. Another argument is based on the energetic advantage which an uptake of intact oligosaccharides provides in comparison to an extracellular or ectoenzymatic cleavage. An essential requirement for uptake of oligosaccharides by Gramnegative bacteria - which are the dominating group of pelagic bacteria - is the effective passage through the outer membrane into the periplasmic space. With $E$. coli accessibility of the periplasmic space for maltodextrins up to a molecular weight of 2500 is enabled by the lamB glycoporine (Ferenci 1980) which has a sugar binding site and is induced in the presence of maltodextrins as well as under nutrient deprivation (Kurlandzka et al. 1991, Death et al. 1993). In contrast to permeation across the outer membrane, transport of sugars into the cytoplasm is restricted to maltosaccharides up to maltoheptaose (Ferenci 1980).

The transport of sugars against a concentration gradient into the cell is an energy consuming process. Muir et al. (1985) impressively showed that uptake of intact oligosaccharides into the cell is energetically more efficient with respect to transport and phosphorylation than external cleavage of the oligosaccharides and the subsequent uptake of the monomeric compounds. Since organic carbon alone or in combination with inorganic nutrients often limits growth of microheterotrophs (Coveney \& Wetzel 1992, Schweitzer \& Simon 1995, Shiah \& Ducklow 1995), it is likely that economy of transport is a key factor in respect to growth efficiency and competition. The immediate decrease of maltose, maltotriose and maltotetraose without a lag phase in the incubation experiments of Lake Au indicates the presence of derepressed transport/uptake systems for oligosaccharides in the bacterial community and characterises oligosaccharides as common substrates of aquatic bacteria. Uptake of the added sugars, with the exception of maltotetraose, was not reflected in an increase of bacterial numbers. When a carbon content of $15 \mathrm{fg} \mathrm{C} \mathrm{Cell}^{-1}$ for pelagic bacteria is assumed, as has been determined for bacteria as in the adjacent Lake Zurich (Button et al. 1996), the complete conversion of the added maltooligosaccharides (216 to $396 \mu \mathrm{g} \mathrm{C)}$ into bacterial biomass would support a 2.2 - to 3.4-fold increase in bacterial counts.
In contrast to the maltooligosaccharides, GPA did not show an immediate and continuous decrease in concentration. A time period of at least $29 \mathrm{~h}$ was necessary to induce a significant drop in concentration. Similar observations have been made by Arnosti \& Repeta (1994) in model systems with anaerobic marine bacteria. These experiments and the present study indicate that disaccharides consisting of a pentose and hexose moiety in combination with a $\beta-(1,3)$-glycosidic linkage do not exhibit very common and suitable substrate features for aquatic bacteria. In contrast to di-, tri- and tetrasaccharides consisting of hexoses, the presence of GPA-type disaccharides in the water of Lake Au was never verified with our mass selective detection system (data not shown).

The average decrease rates of the oligosaccharides in Lake Au have to be considered as conservative since there may be a steady input of oligosaccharides during the incubation period caused by phytoplankton exudation products and cleavage of $\mathrm{DCCHO}$. The rates are within the reported uptake rates for glucose $k 1$ to $>100 \mathrm{nmol} \mathrm{l}^{-1} \mathrm{~h}^{-1}$ ) for freshwater environments (Overbeck 1979, Chróst et al. 1989, Jørgensen 1990, Münster \& Chróst 1990, Jørgensen \& Jensen 1994) as determined by ${ }^{14} \mathrm{C}$-glucose uptake. In experiments by Hanisch et al. (1996) with $1 \mu \mathrm{m}$ filtered lakewater from the mesotrophic Lake Constance, the decrease rates of TDCHO varied between 6.5 and $47.6 \mathrm{nmol} \mathrm{l}^{-1} \mathrm{~h}^{-1}$ (glucose equivalents) and occasionally supplied the complete C requirements of the planktonic bacteria. Since the TDCHO pool is dominated by polymers which are not readily utilizable without previous cleavage, oligosaccharides as cleavage products might have served as substrates in addition to monosaccharides. Therefore, as indicated by the present study, dissolved oligosaccharides may play an important role as energy sources and should not be neglected in the investigation of carbon and energy sources for microheterotrophs.

Acknowledgements. Three anonymous reviewers provided valuable comments on drafts of this paper. We gratefully acknowledge $O$. Köster for his help in data presentation and assistance in field work. We also thank $J$. Corves for data on $\alpha$-glucosidase activity and assistance in field work. This study was partially supported by the Hydrobiologie Limnologie Stiftung, Zürich.

\section{LITERATURE CITED}

Abbt-Braun G, Frimmel FH, Lipp P (1991) Isolation of organic substances from aquatic and terrestrial systems - comparison of some methods. Z Wasser-Abwasser-Forsch 24: 285-292

Allen $\mathrm{MH}$, Vestal ML (1992) Design and performance of a novel electrospray interface. J Am Soc Mass Spectrom 3: $18-26$ 
Aluwihare LI, Repeta DJ, Chen RF (1997) A major biopolymeric component to dissolved organic carbon in surface sea water. Nature 387:166-169

Arnosti C, Repeta DJ (1994) Oligosaccharide degradation by anaerobic marine bacteria: characterization of an experimental system to study polymer degradation in sediments. Limnol Oceanogr 39:1865-1877

Azam F, Hodson RE (1981) Multiphasic kinetics for D-glucose uptake by assemblages of natural marine bacteria. Mar Ecol Prog Ser 6:213-222

Borch NH, Kirchman DL (1997) Concentration and composition of dissolved combined neutral sugars (polysaccharides) in seawater determined by HPLC-PAD. Mar Chem $57: 85-95$

Burney CM, Sieburth JMCN (1977) Dissolved carbohydrates in seawater. II, A spectrophotometric procedure for total carbohydrate analysis and polysaccharide estimation. Mar Chem 5:15-28

Burney CM, Johnson KM, Lavoie DM, Sieburth JMcN (1979) Dissolved carbohydrate and microbial ATP in the North Atlantic: concentrations and interactions. Deep-Sea Res 26A: $1267-1290$

Button DK, Robertson BR, Jüttner F (1996) Microflora of a subalpine lake: bacterial populations, size and DNA distributions, and their dependence on phosphate. FEMS Microb Ecol 21:87-101

Carlson DJ, Mayer LM, Brann ML, Mague TH (1985) Binding of monomeric organic compounds to macromolecular dissolved organic matter in seawater. Mar Chem 16:141-153

Chróst RJ, Münster U, Rai H, Albrecht D, Witzel PK, Overbeck J (1989) Photosynthetic production and exoenzymatic degradation of organic matter in the euphotic zone of a eutrophic lake. J Plankton Res 11:223-242

Coveney MF, Wetzel RG (1992) Effects of nutrients on specific growth rate of bacterioplankton in oligotrophic lake water cultures. Appl Environ Microbiol 58:150-156

Dawson R, Mopper K (1978) A note on the losses of monosaccharides, amino sugars, and amino acids from extracts during concentration procedures. Analyt Biochem 84:191-195

Death A, Notely L, Ferenci T (1993) Derepression of LamB protein facilitates outer membrane permeation of carbohydrates into Escherichia colj under conditions of nutrient stress. J Bacteriol 175:1475-1483

de Haan $H$, de Boer $T$ (1979) Seasonal variation of fulvic acids, amino acids, and sugars in Tjeukemeer, The Netherlands. Arch Hydrobiol 85:30-40

Egli T, Lendenmann U, Snozzi M (1993) Kinetics of microbial growth with mixtures of carbon sources. Antonie van Leeuwenhoek 63:289-298

Ferenci $T$ (1980) The recognition of maltodextrins by Escherichia coli. Eur J Biochem 108:631-636

Fuhrman JA, Bell TM: (1985) Biological considerations in the measurement of dissolved free amino acids in seawater and implications for chemical and microbiological studies. Mar Ecol Prog Ser 25:13-21

Gocke K, Dawson R, Liebezeit G (1981) Availability of dissolved free glucose to heterotrophic microorganisms. Mar Biol 62:209-216

Gremm TJ, Kaplan LA (1997) Dissolved carbohydrates in streamwater determined by HPLC and pulsed amperometric detection. Limnol Oceanogr 42:385-393

Güde H, Haibel B, Müller H (1985) Development of planktonic bacterial populations in a water column of Lake Constance. Arch Hydrobiol 105:59-77

Hanisch K, Schweitzer B, Simon M (1996) Use of dissolved carbohydrates by planktonic bacteria in a mesotrophic lake. Microb Ecol 31:41-55
Hulthe G, Stenhagen G, Fogelqvist (1997) Comparison of dynamic fast atom bombardment/liquid secondary ion mass spectrometry and electrospray mass spectrometry coupled to reversed-phase liquid chromatography for the determination of oligosaccharides in seawater. J Chrom A $777: 141-153$

Ittekkot V, Brockmann U, Michaelis W, Degens ET (1981) Dis solved free and combined carbohydrates during a phytoplankton bloom in the northern North Sea. Mar Ecol Prog Ser 4:299-305

Johnson DC, LaCourse WR (1990) Liquid chromatography with pulsed electrochemical detection at gold and platinum electrodes. Anal Chem 62:589A-597 A

Jones FE, Ditner SA, Freeman $\mathrm{CH}$, Whitaker CHJ, Lock MA (1989) Comparison of a new inorganic membrane filter (Anopore) with a track-etched polycarbonate membrane filter (Nuclepore) for direct counting of bacteria. Appl Environ Microbiol 55:529-530

Jørgensen NOG (1990) Assimilation of free monosaccharides and amino acids relative to bacterial production in eutrophic lake water. Arch Hydrobiol Beih 34:99-110

Jørgensen NOG, Jensen RE (1994) Microbial fluxes of free monosaccharides and total carbohydrates in freshwater determined by PAD-HPLC. FEMS Microb Ecol 14:79-94

Jüttner $F$, Matuschek $T$ (1978) The release of low molecular weight compounds by the phytoplankton in an eutrophic lake. Water Res 12:251-255

Jüttner F, Meon B, Köster O (1997) Quasi in situ separation of particulate matter from lakewater by hollow-fibre filters to overcome errors caused by short turnover times of dissolved compounds. Water Res 31:1637-1642

Karner M, Rassoulzadegan F (1995) Extracellular enzyme activity: indication for high short-term variability in a coastal marine ecosystem. Microb Ecol 30:143-156

Kurlandzka A, Rosenzweig RF, Adams J (1991) Population of Escherichia coli: the role of changes with regulatory and highly pleiotropic effects. Mol Biol Evol 8:261-281

Lendenmann U, Snozzi M, Egli T (1996) Kinetics of the simultaneous utilization of sugar mixtures by Escherichia coli in continous culture. Appl Environ Microbiol 62:1493-1499

Lengeler JW (1993) Carbohydrate transport in bacteria under environmental conditions, a black box? Antonie van Leeuwenhoek 63:275-288

Meadow ND, Fox DK, Roseman S (1990) The bacterial phosphoenolpyruvate: glycose phosphotransferase system. Annu Rev Biochem 59:497-542

Meon B (1997) Zur Problematik der freien Mono- und Oligosaccharide im Seewasser: eine Thermospraymassenspektrometrische Untersuchung am Beispiel des Ausees (Kanton Zürich). (On the problem of free monoand oligosaccharides in lakewater a thermospray mass spectrometrical study at Lake Au (Canton of Zurich). Thesis, University of Zurich (in German)

Mopper K (1977) Sugars and uronic acids in sediment and water from the Black Sea with emphasis on analytical techniques. Mar Chem 5:585-603

Mopper K, Dawson $R$, Liebezeit G, Ittekkot V (1980) The monosaccharide spectra of natural waters. Mar Chem 10: $55-66$

Mopper K, Schultz CA, Chevolot L, Germain C, Revuelta R, Dawson R (1992) Determination of sugars in unconcentrated seawater and other natural waters by liquid chromatography and pulsed amperometric detection. Environ Sci Technol 26:133-138

Muir M. Williams L, Ferenci T (1985) Influence of transport energization on the growth yield of Escherichia colj. J Bacteriol 163:1237-1242 
Münster U (1984) Distribution, dynamic and structure of free dissolved carbohydrates in the Plußsee, a North German eutrophic lake. Verh Internat Verein Limnol 22:929-935

Münster U, Albrecht D (1994) Dissolved organic matter: analysis of composition and function by a molecular-biochemical approach. In: Overbeck J, Chróst RJ (eds) Microbial ecology of Lake Plußsee. Ecological Studies 105, Springer-Verlag, New York, p 24-62

Münster U, Chróst RJ (1990) Origin, composition, and microbial utilization of dissolved organic matter. In: Overbeck $J_{,}$ Chróst RJ (eds) Aquatic microbial ecology. Brock/Springer Series in Contemporary Bioscience, Springer-Verlag, New York, p 8-46

Münster U, Einiö P, Nurminen J (1989) Evaluation of the measurements of extracellular enzyme activities in a polyhumic lake by means of studies with 4-methylumbelliferylsubstrates. Arch Hydrobiol 115:321-337

Niessen WMA, Van der Hoeven RAM, Van der Greef $J$, Schols HA, Voragen AGJ (1992a) On-line liquid chromatography/thermospray mass spectrometry in the analysis of oligosaccharides. Rapid Commun Mass Spectrom 6: 197-202

Niessen WMA, Van der Hoeven RAM, Van der Greef J, Schols HA, Lucas-Lokhorst G, Voragen AGJ, Bruggink C (1992b) High-performance anion exchange chromatography/thermospray mass spectrometry in the analysis of oligosaccharides. Rapid Commun Mass Spectrom 6: $474-478$

Nissen H, Nissen P, Azam F (1984) Multiphasic uptake of Dglucose by an oligotrophic marine bacterium. Mar Ecol Prog Ser 16:155-160

Overbeck J (1979) Studies on heterotrophic functions and glucose metabolism of microplankton in Plußsee. Arch Hydrobiol Beih Ergebn Limnol 13:56-76

Pakulski JD, Benner R (1992) An improved method for the hydrolysis and MBTH analysis of dissolved and particulate carbohydrates in seawater. Mar Chem 40:143-160

Pakulski JD, Benner R (1994) Abundance and distribution of carbohydrates in the ocean. Limnol Oceanogr 39:930-940

Rich JH, Ducklow HW, Kirchman DL (1996) Concentration and uptake of neutral monosaccharides along $140^{\circ} \mathrm{W}$ in the equatorial Pacific: Contribution of glucose to heterotrophic bacterial activity and DOM flux. Limnol Oceanogr 41:595-604

Editorial responsibility: Farooq Azam,

La Jolla, California, USA
Sakugawa H, Handa N (1985) Chemical studies on dissolved carbohydrates in the water samples collected from the North Pacific and Bering Sea. Oceanologica Acta 8:185-196

Schanz F (1982) A fluorimetric method of determining chlorophyll a and phaeophytin a concentrations. Arch Hydrobiol Beih 16:91-100

Schweitzer B, Simon M (1995) Growth limitation of planktonic bacteria in a large mesotrophic lake. Microb Ecol 30 89-104

Senior W, Chevolot L (1991) Studies of dissolved carbohydrates (or carbohydrate-like substances) in an estuarine environment. Mar Chem 32:19-35

Shiah FK, Ducklow HW (1995) Regulation of bacterial abundance and production by substrate supply and bacteriovory: a mesocosm study. Microb Ecol 30:239-255

Simpson RC, Fenselau CC, Hardy MR, Townsend RR, Lee YC, Cotter RJ (1990) Adaption of a thermospray liquid chromatography/mass spectrometry interface for use with alkaline anion exchange liquid chromatography of carbohydrates. Analyt Chem 62:248-252

Stabel HH (1977a) On the problem of the determination of dissolved carbohydrates with the anthrone-method. Arch Hydrabiol 80:216-226

Stabel HH (1977b) Bound carbohydrates as stable compounds in Lake Schöhsee and in cultures of Scenedesmus. Arch Hydrobiol Suppl 53:159-254

Strobel HJ, Caldwell FC, Dawson KA (1995) Carbohydrate transport by the anaerobic thermophile Clostridium thermocellum LQRI. Appl Environ Microbiol 61:4012-4015

Van der Hoeven RAM, Niessen WMA, Schols HA, Voragen AGJ, Van der Greef J (1992) Characterization of sugar oligomers by on-line high-performance anion-exchange chromatography-thermospray mass spectrometry. J Chromatogr 627:63-73

Vestal ML (1984) High-performance liquid chromatographymass spectrometry. Science 226:275-281

Vrba J, Nedoma J, Simek K, Seda J (1992) Microbial decomposition of polymer organic matter related to plankton development in a reservoir: activity of $\alpha$-, $\beta$-glucosidase, and $\beta$-N-acetylglucosaminidase and uptake of $\mathrm{N}$-acetylglucosamine. Arch Hydrobiol 126:193-211

Wells GB, Lester RL (1979) Rapid separation of acetylated oligosaccharides by reverse-phase high-pressure liquid chromatography. Anal Biochem 9:184-190

Submitted: March 3, 1998; Accepted: July 12, 1998

Proofs received from author(s): December 14, 1998 